\title{
Medieval Kazakh History in Arab and Persian Sources
}

\author{
Adil Markhaba ${ }^{1 *}$, Islam Zhemeney ${ }^{2}$, Aman K. Rakhmetullin ${ }^{1}$, Kalamkas B. Bolatova ${ }^{1}$ \& \\ Aigul S. Adilbayeva ${ }^{1}$ \\ ${ }^{1}$ Department of History and Social Sciences and Humanities, Kazakh Humanitarian Law \\ Innovative University, Semey, Republic of Kazakhstan. Email: markhaba6563@kpi.com.de \\ 2"Turan-Iran" Research Center, Al-Farabi Kazakh National University, Almaty, Republic of \\ Kazakhstan
}

\begin{abstract}
The relevance of this topic lies in the analysis of the study of medieval Kazakh history. After gaining independence, the processes of the revival of national identity, reinstatement of primitive spiritual and moral values and human mentality, which were sharply suppressed during the period of the Soviet totalitarian system, became widespread. Therewith, the widely discussed national-historical structure of the population, the knowledge of ethnic roots, the restoration of traditions and customs, which served as a connecting link, as well as the specificity and originality of the approach are of particular importance. Currently, the problem of objective reading, coverage, and popularisation of the ancient and medieval Kazakh history and culture is acute. By rejecting one-sided interpretations of historical events, established clichés require impartial, academic analysis based on evidence drawn from a wide range of sources. The purpose of this study is to identify the problems of the history of Kazakhstan in the 13th-14th centuries, the general laws of world historical development and the features of the historical process, folk traditions by using a scientific and systematic approach. Based on the systematisation and classification of data from the geographical and Arab historical records of the 13th-14th centuries, the analysis of written monuments is performed, their interdependence is established, and the degree of completeness and reliability of the data in the works of the narrative is determined in an integral system. Due to the scientific expeditions and research trips to Mongolia, China, and Germany, Kazakh orientalists analysed and performed the first systematic processing of archival materials and historical evidence of the early history of resettlement based on the ancient Turkic manuscript, ancient Indian, and Chinese sources that formed a picture of the proto and ancient history. For example, the features of stone figures give an idea of the military hierarchy, military operations, the settlement of ethnic groups (ethnogeography), the worldview of the Turks, etc.
\end{abstract}

Keywords: history of Kazakhstan, written monuments, source study, analysis, Arab and Persian historical works.

\section{Introduction}

The scientific need for the development of a number of imperative historical problems related to the development of statehood, the ethnic territory, the definition of cultural heritage and the demonstration of the common historical fate of the peoples of Kazakhstan and Central Asia, is associated primarily with the reliable source database (History of Kazakhstan in..., 2017). As Kazakh and foreign research shows, every period of Kazakh history is associated mainly with the

This Open Access article is published under a Creative Commons Attribution Non-Commercial 4.0 International License (http://creativecommons.org/licenses/by-nc/4.0/), which permits non-commercial re-use, distribution, and reproduction in any medium, provided the original work is properly cited. For citation use the DOI. For commercial re-use, please contact editor@rupkatha.com. 
information provided by certain cultural and historical written traditions (Nazzal et al., 2019). Thus, antiquity is represented by the ancient Iranian, ancient Greek, ancient Roman and partly ancient Chinese chronicles. The history of the early Middle Ages (6th-8th centuries) is based primarily on Chinese and ancient Turkic written monuments. As for the period of the 9th-12th centuries, the primary source on the history of Kazakhstan, Kyrgyzstan, Uzbekistan is the Arabic historical and geographical works written in the 9th-15th centuries. Notably, the Arabic scriptures, which were created after the 12th century, are mostly a compilation that portray historical events of previous centuries (Barak, 2019; He, 2019).

Arabic monuments (both individual works and compilations) have been repeatedly involved in the historical development by generations of scholars. Some historical and source study experience has been accumulated. However, the analysis of Arabic sources of the 9th-15th centuries has not been performed within a holistic approach until now. This approach will make it possible to realistically assess the degree of completeness and reliability of the available information and identify those internal connections that turn the selection of real fragments from different sources into an internally non-contradictory system, which is a reliable background for new evaluations and conclusions in the study of the history and culture of Turkic peoples (Gumilev, 2003a).

The most potent historical literature published in oriental languages reflects the history of the peoples of Central Asia. Persian sources hold a special place among the inscriptions of the 13th-15th centuries associated with the history of Kazakhstan. Some of them are being carefully studied to this day. The written sources of the Golden Horde have not survived (with the exception of a few khan labels). Therefore, the messages of the authors of Persian works are of particular importance. From the second half of the 13th century, the Arabic language was replaced by Persian in the Middle East and Central Asia, which was used for writing prose pieces and documentary monuments until the beginning of the 20th century in the Central Asian region (Artamonov, 2005).

An analysis of the written Arabic and Persian monuments, starting from the earliest ones, allows for identifying the sources of information and the interdependence of medieval authors, pinpointing parallel places in different plots, fact-checking information based on rumours or traditional ideas. The analysis of sources reveals the primary and secondary information to the history of Kazakhstan and neighbouring regions of Central Asia (Hautala, 2019; Stănică, 2018). The systematic approach also allows for viewing the data of the sources not in the chronological order of the writing of the essays but in the time of the primary sources' emergence (Peacock, 2018). The study of Arabic and Persian sources is a necessary step in developing new historical generalisations.

\section{Literature Review}

Some sources were collected by the famous orientalist V.G. Tizengauzen (1941) and published after his death in 1941. The second volume of the "Collection of Materials on the History of the Golden Horde" contains excerpts from the works of Persian-speaking authors, processed by A.A. Romaskevich, A.Yu. Yakubovskiy and S.L. Volin (1939). Professor A.A. Romaskevich was a student 
of an academician K. Zaleman, professor V. Zhukovsky and academician V. V. Bartold. He was the author of many works of Iranian studies. S.L. Volin has written the initial information provided for the translation of the excerpts. They did a wonderful and meticulous job since not all of V.G. Tiesenhausen were processed and prepared for publication (Volin et al., 1939).

When acknowledging the great work that A.A. Romaskevich and S.L. Volin, A. Yu. Yakubovskiy (1939) noted: "Several years that have passed since the publication of this work showed how much this book was needed. It is referenced frequently in historical works. When generalising over a century-old work on this vast and complex issue by Russian and Western European scholars, the long-term and meticulous research of the Russian researcher V.G. Tizengauzen (1941) has to be appreciated as a cultural heritage. At the moment, none of the historians studying the Golden Horde can omit to pay attention to the materials he has collected" (Bichurin, 2008).

Indeed, in addition to A.Yu. Yakubovskiy, there are other recognised scholars on various issues of the history of the Golden Horde, who extensively used the information from the "Collection": G.A. Fedorov-Davydov ("The Social System of the Golden Horde", 1973; "The Art of Nomads and the Golden Horde", 1976) (Archive of textbooks..., 2021), M.G. Safargaliev ("The Disintegration of the Golden Horde", 1960), M.A. Usmanov ("Acts Granted by the Juchiev Ulus of the 14th-16th centuries", 1979), B.A. Akhmedov ("The State of Nomadic Uzbeks", 1965), V.P. Yudin ("Hordes: White, Blue, Gray, Gold ...", 1983), Utemish Haji ("Chingiz-name", 2001), V.A. Egorov ("Historical Geography of the Golden Horde in the 13th-19th centuries", 1985), Devin Davis ("Islamisation and Native Religion in the Golden Horde", 1994), B.B. Irmukhanov ("The Past of Kazakhstan in Written Sources of the 5th century BC - 16th century AD", 1998), A. Arslanov ("Remaining Books from the Times of the Past", 2002), authors of collections of articles ("Desht-i Kipchak and the Golden Horde in the Development of the Culture of the Eurasian Peoples", 2003; "Materials on the Ethnic History of the Turkic Peoples of Central Asia", 2003; Amitai Reuven, Michal Biran, Eds. "Mongols, Turks, and Others. Eurasian Nomads and the Sedentary World", 2005) and others (Gumilev, 2003b).

When publishing the second volume of "Collection", A.A. Romaskevich and S.L. Volin decided to exclude a number of works by later Persian-speaking authors, believing that they used the works of their predecessors. "Mujmal-i Fasikhi" ("Fasikhov's vault") by Ahmad ibn Jalal ad-din Muhammad al-Khawafi, Mavarannahr and Dasht-i Kipchak was among them. The description of events is given in chronological order, the author indicates the year when this happens and lists all significant events. In the new edition of the "Collection" in the commentary on the works of "Jami 'at-tavarih", "Ta'rikh-i Guzida", "Ta'rikh-i Shaikh-Uvays", additional materials from "Mujmali Fasikhi" related to the history of Ulus Jochi were included (Bichurin, 2013).

A.A. Romaskevich and S.A. Volin included extracts from the "Genealogy of the Turks" in the "Collection", which were made in accordance with the extracts of V.G. Tiesenhausen from the British Museum manuscript and compared with Miles's translation. Researcher Miles and V.G. Tizengauzen afterwards came to the conclusion that this work is "Shajarat al-atrak" by having incorrectly translated an excerpt from the work on the reign of Sain Khan. The author of the abridged version of the manuscript, when finishing one's work, writes: "This manuscript is "Ulus-i arba'-i chingizi and the listing of the names of the rulers [from] the descendants of Turk-khan ibn 
Yafis ibn Nukh, may thy be in piece, the names of the Khakans of Turkestan- zamina, given in this treatise, are transferred from the collection, which was composed by Sultan as-Sa'id Ulugbek Mirza the Martyr, may Allah shed light on his grave, about the Khakans of the four uluses". As far as possible, the found errors have been corrected (Bichurin, 2013).

The work of 'Ata-Malik Juvaini "Ta'rikh-i Jahangushay" ("History of the Conqueror of the World") is one of the valuable Persian sources dedicated to the history of the conquest campaigns of Genghis Khan and Genghisids. It provides a detailed summary of the Mongol campaigns from the first conquests of Genghis Khan to the campaign of Hulagu-khan against the Isma'ilis and their following destruction in 1257. Many historians of the next generations used it as a primary source, which is mostly an eyewitness testimony (Toonen et al., 2020).

\section{Materials and Methods}

In the course of this study, the sources of historical and geographical writings, passenger notes, cosmographic works, and encyclopaedic books were analysed. The systematic approach allowed for covering a wide range of Arab and Persian historical writings on the history of Kazakhstan and neighbouring regions of Central Asia from 9th to 11th centuries. Analysis of the source study of the corpus of Arab and Persian written monuments identified the interdependence of medieval works since the accumulated data in Arab and Persian narrative works was perceived by writers as a common heritage regardless of the time and place of their origin (Stein, 2018).

Primary and secondary information related to the history of Kazakhstan and Central Asia was identified. This approach is the key to determining the chronological order of certain messages by medieval authors, which is fundamental for the analysis of geographical materials, where dates or other attributes are completely absent. Preliminary information was also provided. At the same time, when analysing sources, the definition of authentic and composite materials was slightly revealed. Accurate data is mainly related to travel information. Due to the frequent repetition of the first messages, the information from the unsaved records of the first Arab and Persian travellers who crossed the territory of Kazakhstan was retrieved. These are Sallam atTarjuman (mid-9th century) in the writings of Ibn Khordadbeh, Ibn Rust. and al-Idrisi; Tamim ibn Bahra (early 9th century) in the book of Ibn al-Fakih, which excerpts were preserved in the works of Qudam ibn Jafar, Ibn Khordadbeh, Yakut al-Hamawi (Motavalian Naeini \& Dehkhodaei, 2018; Shingiray, 2018).

Arab and Persian historical and literary works of famous medieval authors hold a special place in the study of sources in Kazakhstan. This section of historical works contains important information about the medieval history of Kazakhstan. The Arab conquests of the Arabian Peninsula in the East contributed to the study and accumulation of knowledge about new countries by Arab scholars and officials. This policy is associated with the expansion of influence of the Muslim religion and culture within regions far from the development of trade relations, which were in under influence of or in pre-Islam countries. Thus, Arab guests and officials collected information about the lands and peoples of Eastern Europe and Central Asia. They were especially interested in the vast territory from Altai to Afghanistan. This interest was associated with the 
unification of the Arab-occupied countries of Central Asia and the strengthening of close ties with the tribal settlements of nomadic warriors.

The first mention of the territory of Kazakhstan can be found in the Arab sources of the 9th century. The most famous authors such as al-Balazuri and at-Tabari provide various information about the Turkic peoples of Semirechia and South Kazakhstan. This information was presented due to the significant help of the Turkish tribes to the inhabitants of Central Asia in the fight against the Arab invaders. The "Book of the Conquest of the Lands" by al-Balazuri (Kitab futuh al-Buldan) is one of the important and valuable works of this period. The author describes the process of entering the orbit of Arab influence in the territory of Central Asia and neighbouring countries of South Kazakhstan quite accurately. The main sources on the history of Kazakhstan include works written in Persian in Central Asia and neighbouring countries. Many important issues in the history of Kazakhstan still require an in-depth study with a much greater accumulation of various factual elements, their generalisation and analysis.

Historical works on the history of Kazakhstan in Persian are presented mainly in the chronicles. They usually combine works of a very different nature and content, from simple lists of rulers to writings that can be called detailed historical treatises. Historical knowledge about the initial stage of the emergence and development of humanity is based on the study of cultural monuments left by ancient people such as tools, camps, rock paintings, burials. Written sources about the ancient inhabitants of the Protokazakh territory appeared much later. Among them are Persian, Greek, Latin, Arab, Turkish, and Chinese written sources. They contain information about ethnogenetic processes, relations with neighbours, political events, economic activities, the way of life of the tribes in this country. Thus, sources constitute the basis of historical knowledge.

Numerous works published in the field of archaeology, ethnic anthropology, ethnography, ancient and medieval history, which main factual and theoretical positions are still recognised. Even from an ideological standpoint, this literature is an important source for studying the evolution of historical thought, and contains most of the specific historical information required for a critical approach at the same time. The process of national identity awakening, the spiritual revival of the nation developed rapidly, anticipating the development of problems in history, language, literature and moral categories. During the development of historical consciousness, the history of the home was needed in the first place (Dalelbekkyzy et al., 2019). This is explained by: a) the need to understand the history of humankind; b) the need for a theoretical understanding of a new type of independent sovereign state; c) accelerate the process of achieving independence and the spiritual revival of the economic republic.

The crucial role of written Arabic and Persian sources in this study and reconstruction of the medieval history of Kazakhstan is emphasised. Notably, the role of the national programme "Cultural Heritage" is significant as it enabled research and publication of important historical works of ancient Eastern authors, who portrayed the development of history, ethnography and culture of the people and the state. 


\section{Results}

Historical sources are material objects and written documents reflecting the history of the development of human society. For history to be scientific and objective, it must first of all be based on reliable sources. Therefore, one of the basic principles of history as a discipline is documentation. Historians say that there is no history without documents. Historiography is the history of historical science. It includes the dynamics of historical knowledge, information about historical events, the identification and description of new sources, and the development of methods, approaches, principles of historical research at the same time.

Materials discovered by eastern archaeographic expeditions (2004-2009). They are unique in foreign archives, funds, libraries, museums (2). They were the basis for translations from oriental languages with full scientific capacities: commentaries, glossaries, indexes, scientific research. For the period 2004-2009 a series of books (30 volumes) have been issued, including "History of Kazakhstan in Persian, Turkic, Arab, Chinese, Mongolian, Armenian sources", "History of Kazakhstan in Oriental Miniatures", "Manuscript Artifacts from the Anri Moser Fund about the History and Culture of Kazakhstan", "Shakpak ata", "Collection of Archival Documents about the Chinese-Kazakh Relations of the Qing Period" (2 facsimiles, 4 volumes), "The Rarity of the Applied arts of Kazakhs Abroad", etc.

The initial history of the Kazakh people was adapted to general laws of a pharmaceutical nature, schematic, important events and facts. Significant historical figures, whose activities did not fit into the doctrinal principles of official ideology, have not followed it. The tragedies of history have faded. The richest cultural and historical heritage of the Kazakh people and the role of nomadic civilisations in world history were underestimated. The development of global culture was associated only with a sedentary lifestyle and economic activity. All the achievements of human culture and technology were attributed exclusively to European civilisation. A lower status of the ethnogenesis of small peoples, a more subtle origin in comparison with the Slavic peoples, their statehood, the voluntary accession of the Kazakhs, and much more were just assumed. The history of Kazakhstan was artificially separated from the history of the peoples of Central Asia. The people were deprived of the opportunity to find out where their historical roots were, what place they held in the history of Europe and Asia, what were their present relations with other countries and peoples in the past (Stănică, 2018).

The history of each nation has always developed with interaction with other nations and their cultures. This means that the history of a person and their interactions have been depicted and reflected in other cultural areas, regardless of latitude and longitude. Therefore, information and documents on the history and culture of the Kazakh people were recorded both by their closest neighbours and by those who, by the will of fate, crossed the territory of the Kazakh steppe and laid an impact on their descendants. Up until recently, the history of the Kazakh Khanate was studied only through certain types of sources. Scholars are obliged to search for new materials that will help fill the "gaps" in history and, above all, come closer to an objective understanding of the processes that took place in the past. Due to the state program "Cultural Heritage", it was possible to study the sources of Kazakhstan through unique exhibits and copies of archival materials from abroad, as well as to supplement and expand the information and historical 
database. Funding is of great importance for an objective study of the history of Kazakh statehood (Turysbek et al., 2021).

Within the framework of the "Madeni Mura" programme, eastern archaeological work was performed in the Russian Federation, China, Mongolia, Kyrgyzstan, Turkey, Armenia, Hungary and Switzerland. The specific results of the work of archaeological expeditions are unique and are reflected in the books published under this programme (Magsumov et al., 2019a; Magsumov et al., 2019b; Ermachkov et al., 2020). They laid a solid foundation for the work of a large team of scholars focused on recreating the ancient and medieval history and culture of the Kazakh people. The data of unknown and little-known sources in Kazakh historical science, which are of particular importance for studying the history of the formation of the national idea and the spiritual culture of the Kazakh people, are widely studied from a new perspective.

For the first time, the scientific circulation includes numerous sources that reflect all stages of historical development and cultural traditions of the Kazakh people. The eastern archaeographic expedition was performed in two directions. Firstly, it was the identification of historical monuments of the 6th-9th centuries. The Turkish period is associated with ethnogenesis and prehistory of Kazakhstan. Secondly, it was a collection of archival documents related to the history of trade, economic, diplomatic, historical and cultural relations of the Kazakh Khanate with neighbouring countries. Also, documents about diplomatic relations such as Kazakhstan-China, Kazakhstan-Russia, Kazakhstan-Kyrgyzstan, Kazakhstan-Kokand, Kazakh-Airat, everyday life, Kazakhstan customs, and other documents were found. The collection is part of a Kazakh-Chinese project. The "Archival documents on Kazakh-Chinese Relations during the Qing dynasty" published facsimiles of the listed documents (volumes I-II). The four volumes of these documents were translations into Kazakh language. There were also archival documents of the first historical archive of China, including the office, diplomatic correspondence and the exchange of ambassadors, which is also confirmed by unique works in the form of beautiful drawings, miniatures, photographs and applied art.

While working with the collections of Parisian libraries and museums, a unique painting "Kazakhs Donate Horses" was discovered. It was found in the famous Parisian Museum of Oriental Art Guimet, where art relics of the East are kept. This is the only painting from 1757 that depicts a diplomatic gift-giving ceremony involving three horses. The painting depicting three Kazakh envoys and three horses confirms the fact that the Kazakhs presented gifts to the Chinese Emperor Tianlong as a sign of unity and friendship. The artist of the painting is the Italian man Giuseppe Castiglioni, who was the court artist of the Emperor of Tianlong, who captured historical and ethnographic objects. The image depicts clothes, household items of that time. The fabric is of considerable importance in the study of clothing and reflects the richest symbolism (Auanasova et al., 2019; Auanasova et al., 2021). Despite the insignificance of archaeological finds in this regard, it is still possible to imagine what kind of fabrics were used in Kazakhstan in the 16th-18th centuries. Analysis of the image concluded that the historical events depicted in this painting date back to the reign of Abilai Khan in Kazakhstan and Emperor Qianlong in China.

At the beginning of the 18th century, the system of international relations in Central Asia underwent significant changes. The Dzungar Khanate was a large and influential country in the region until the middle of the 18th century. The Qing Empire and Russia expand their influence 
on international relations in Central Asia significantly. In fact, the relations that developed at that time between China and Kazakhstan were ordinary political and diplomatic contacts. History proves none of the civilisations arose separately, in isolation from other cultures. During all stages of development, they complemented each other. The development of the problems of historical and cultural relations between peoples from ancient times to the present day is becoming increasingly important to understand the complex historical processes that took place in the vast territory of Eurasia correctly.

Kazakhstan and Central Asia have always attracted the attention of Western European travellers with their advantageous geographical position, natural resources, and ancient primordial culture. Therefore, the rich collections of cultural artifacts, documents, memoirs of Western travellers, currently stored in museums and archives in Europe and America, are essential for the study of the history and culture of Kazakhstan and Central Asia. Performed within the framework of the National Programme, scientific expeditions from the Institute of Oriental Studies to museums in Europe and Asia are also valuable for collecting sources on the history of the culture of the Kazakh people. "Madeni Mura" was used to identify artifacts, historical monuments of applied art in Kazakhstan, similar phenomena in art in their funds. Reaffirming the cultural interaction that took place in history, the discovered exhibits have been introduced into scientific research and supplement the available data, which have been limited mainly to the materials available to researchers in museums in the post-Soviet space until now.

The exhibits discovered and registered in the fund of the Bern Historical Museum are significantly informative for giving a more holistic picture of the historical and cultural heritage of Kazakh people. Most of the exhibits are from the 18th-19th centuries. These rare exhibits are a significant addition to the political history of Kazakhstan, and also represent examples of the artistic creativity of the Kazakh people. Some of them are presented in a single copy and have no analogues in the museum collections of Kazakhstan. In addition, various categories of items such as wall friezes, garments, belts with pendants, raincoats, weapons and women's jewellery were collected here. Among the exhibits, a long wall frieze (tusquil) with a rich ornamental applique, which reflects the hierarchy of Kazakh society, stands out. In itself, it is a new potential for the study of not only the material culture of Kazakhs but also the political history of Kazakhstan. Some of the exhibits provide new information related to ethnography and semantics of the traditional arts of the Kazakh people, which contributes to research results. The collection includes exhibits of another ethnic group that existed in the Kazakh region, evidence of broader diplomatic, trade, economic and cultural ties of the Kazakh people with neighbouring countries.

Other recognition and study in the funds of A. Moser is necessary and promising for the restoration of objective national history and identity. Documents on the history of Kazakhs stored in the collections of the Berne Historical Museum reflect the historical continuity and traditions of the development of the state. An in-depth study of new manuscript material and a parallel comparative study of information from known and unknown documents and their inclusion into scientific research will allow for studying all stages of the historical development of Kazakh society (the emergence and development of the ancient Turkic, pre-Mongolian, Mongolian and Kazakh Khanate). 
In 2013, the President of Kazakhstan N.A. Nazarbayev launched a new state program "Halyk tarikh tolkynynda" focused on finding new sources that could shed light on the understanding of the history and culture of the Kazakh people with its own features as part of global history. Research in this field is very important for the development of cultural identity and broader modern development since the origins of many contemporary problems go back to antiquity and the Middle Ages. Another important consequence is the development and modernisation of the school of national oriental studies and historiography, which are the main disciplines that make up the intellectual heritage of the entire country. For this matter, the Republican Information Centre for the Study of Historical Materials (RIC) was established in 2013 at the Institute of Oriental Studies named after R.B. Suleimenova. The main direction of the RIC's work is a large-scale collection, study, translation, digitisation, and organisation of mass distribution of archival documents mentioning the history of the Kazakh people in Kazakh, Russian and English.

In addition to written sources, many artifacts and stone statues, stone inscriptions of the Mongols and ayrat have survived. All these artifacts are poorly studied. Thus, the goal of the project is to search for unknown materials and include them in the scientific research. Historians were given the difficult and responsible task of reviewing, studying and writing national history based on a huge number of new (rich, archaeological, oral, cartographic, artifacts and other sources) archives that are still unrecognised and distributed in various foreign archives. These materials have not been studied for centuries. Within the framework of the People in the Stream of History programme, academic trips to foreign funds of Iran, India, India, China, Egypt, Turkey, Mongolia were organised to discover new archival materials on history and culture.

During the scientific expeditions to Mongolia, China and Germany, Kazakh orientalists analysed and developed the first systematic processing of archival materials and historical evidence of the early history of resettlement based on the ancient Turkic manuscripts, ancient Indian and Chinese sources, describing the proto and ancient history. For example, the attributes of stone figures give an idea of the military hierarchy, military operations, the settlement of ethnic groups (ethnogeography), the worldview of the Turks, etc. (Dautova et al., 2017; Ermachkov et al., 2021). The ethnic composition and geographical distribution of nomadic peoples have been studied through numerous documents from Syrian, Turkish (carved in stone) and Chinese sources not only in Kazakhstan, but also in Central Asia. The new material allowed for creating a system of inheritance of supreme power from the old Turks.

The study of Turkish epitaphs and Nestorian monuments preserved along the Great Silk Road is of great importance. A comparative analysis of the texts of Nestorian monuments on the territory of Kazakhstan, Kyrgyzstan and China reveal a number of issues of the ethnogenesis of the Kazakh people, the history of religions (Begalinova et al., 2020), the history of the development of the Turkish language and writing. The work done by the participants during the assimilation of the acquired material, their combination and qualitative analysis are very important for the restoration of historical memory, especially the history of the structure and development of the Turkic Archaeological excavations of Turkic prehistoric times of Genghis Khan. Generalisation of the works of the pre-Mongols and the cities of Maverannahr such as "Tarikh-i al-Saljuk", "Tarikhi Jalal-ad din Khorezmshah", "Maj al-ansab", "Tarikh-i Uljaytu" was performed. 
The official letters of Khan Abyly, which have a unique meaning, are of great interest. Letters and other documents signed by Khan Abylai reveal that, despite the great distances in modern time and the lack of familiar connections, the state of Kazakhstan and China had very close relations. An analysis of the archival documents presented the headquarters of the khans in Kazakhstan had cabinets that issued khan's diplomatic and socio-economic decrees. The preliminary results of work on the platform for editing and cataloguing catalogues show how much there is new information on the history and culture of Kazakhstan, and how much remains to be learned and studied. Their analysis, and a comparative analysis of available resources will bring solutions to key issues such as the process of ethnogenesis of Kazakhs and other Central Asian peoples, the structure of the state and its maintenance. The last minute is very important for studying the history of the Kazakh Khanate, the 5050th anniversary of which is celebrated in 2015.

The vast and scattered materials obtained during archaeological expeditions require careful and scrupulous analysis over time, especially as new materials become available. It seems important to register and submit new significant historical documents describing important milestones in the history of Kazakhstan. These documents are presented as "a consolidated catalo of written, oral, epigraphic sources and artifacts on the history of Kazakhstan", which considers the main types of sources identified during the programme, and new approaches and research methodologies that are crucial for understanding history.

"Integrated catalogue" is the result of systematisation, cataloguing and digitisation of the received material. This is the first but very important step in the creation of a new series of materials and documents, which will expand as new sources are identified and developed. It is planned to create a specialised independent catalogue for certain types of sources in the future. Thus, various historical and cultural sources and materials of Kazakhstan will be distributed to various foreign databases, and a new unique database will be created within the framework of the Republican Information Centre (RIC) for the first time. When compiling the "Consolidated Catalogue", the materials found were systematised according to four main sources types, which are written, oral, epigraphic and exponential. Each is classified for each type of function. For example, written sources are Persian, Turkic, Arabic, etc., divided into epigraphic according to the place of origin (for example, according to geographic location); exhibited by type: Orkhon, Yenisei, Uygur, etc.

At the moment, the search for new historical materials is an ongoing process, a comparative analysis is performed with already known templates and lists. All this affects the state and development of source study as a special scientific discipline, where interaction with researchers from other countries, as well as with the largest scientific centres of the world, is necessary. New discoveries, testifying to the history and culture of Kazakhstan, are direct evidence that the thousand-year traditions of Kazakh people are an important integral part of global history and contribute to its treasury in a particularly unique way. 


\section{Discussion}

The work of the Arab geographer and traveller al-Idrisi is a significant monument of the mid-12th century. The author of Nuzhat al-mushtak Fihtirak al-Afak visited European and Muslim countries. His works contain a variety of information about the countries of Europe, Asia and Africa. In his work, al-Idrisi described the Turkic tribes, mentioning the Kimaks, Gypsies, Karluks, Oghuzes and others. A feature of the work of this Arab author is the use of various historical sources known to him but not preserved to this day. The geographical maps from the work of Al-Idrisi "Surat al-ard" (Face of the Earth) are of particular interest. Maps are important for identifying various geographic and economic features, which are a great addition to written information.

At the beginning of the 13th century a number of works have been created that mention peoples or other information about the territory of Central Asia and Kazakhstan. These works include the List of States (Mujam al-Buldan) by the Syrian scholar Yakut. This work is specific and geographic. Yakut included information on geography, ethnography, history, folklore and other information created before and at his disposal. Special emphasis is put on the Turkish peoples and their culture. The work mentions the invasion of the Mongols and the movement of their troops across the territory of Kazakhstan. Another Arab scholar Ibn al-Atir, who lived at the beginning of the 12th-13th centuries, was a contemporary of the Yakut. This author presented the information he knew in the book "A Complete Description of History" (Al-Kamil Fittarih). His work contains valuable information about the political history of different countries, including the Arab Caliphate, Samanids, Karakhanids, Khorezmshahs and others. This work is important for the study of the medieval history of Kazakhstan, since there are ethnic, historical, cultural and ethnographic materials. The book contains a description of the consequences of the Mongol invasion in Central Asia and Kazakhstan.

At the same time, there are important tools for the cultural heritage of the Kipchaks, the economic and cultural nature of the Kipchaks, their way of life, their beliefs, their customs and traditions. The information of ancient writers proves that in Dasht-i Kipchak the Mongol dignitaries, who began to seize all the rights of political power, gradually intervened and invaded the encirclement of Kipchak Turkey. The developed Kipchak culture won the war between two cultures. Thus, the traditional customs of the Kipchaks deceived the Mongols. The ideas related to the development of the state and cultural traditions turned out to be so strong that they reappeared at the end of the 13th century during the formation (later Mongol invasion) of the first indigenous country of Ak-Orda based on the Kipchak ethnic union.

The absence of a solid, holistic, and critically illuminated history of the Golden Horde or the Juchid ulus, i.e., the legacy of the descendants of Jochi, the eldest son of Genghis Khan, is one of the most important and visible gaps in Kazakh description of everyday life that deprives of the opportunity not only to get acquainted with current affairs and the entire system, which was this huge and original semi-steppe force ruled the fate of Russia for two centuries, but also correctly assessed the degree of its influence on Russia, determining confidently that this Mongol-Tatar domination was reflected on Kazakh and how much it slowed down the natural development of the Russian people. In 1805, Schlözer emphasised the importance and necessity of studying the "Mongolian period" of Russian history, calling it the enviable fate of scholars who would be engaged in this interesting work. The reign of the Mongol dynasty, known as the Golden Horde 
period and among Muslims as Ulus Jochi, or Genghis Khanate Desht Kipchak, and among the Great Mongols themselves as Togmak period, which was an almost two and half a century horror and disaster in Russia, kept it under slavery and had a rebellious crown and the lives of their princes. Domination should not have more or less influence on the fate, structure, decisions, education, morality and language of the motherland.

There were printed and handwritten texts in Arabic, Syriac, Persian and Turkish, Mongolian, Chinese and Armenian languages. Notably, there is no unique history of this origin in oriental languages, or at least they are not kept in any of the European libraries, which do not have many oriental manuscripts, since details of such a structure, or the Turkish life historian Haji Khalifa, or the Muslim historian reading his sources are not found. However, the main tools for this work are hidden in various stories around the world: Crimean cannabis, cannon-chans, descendants of Timur, and others. Here The most important creations that can serve the purpose of this study are mentioned. These include published works of Abu al-Faraj (his Arab and Syrian history), Galton, Abu al-Fida (in his historical and geographical reports), Ibn Battuta (in English), Timurov, Ibn Arabshah, History of the Kazan Empire, compiled by the Tatars of Abu-al-Ghazi, converted to Christianity, the life of Genghis Khan and Aksak Timur, Stefan Orpelyan, Sanang-Setsen, Yuan-Se, a Sung singer - Liana, Gobil and Malyak; Muslim manuscripts: Rashid ad-dinov Jami at-tavarih (in Persia, the first part of the Asian Academy Museum and the Imperial National Library). In addition, there are many other Arab, Persian and Turkish historians but they are not present in the lists of Kazakhs in libraries yet. Two of them, who are perhaps the most important, were not found in foreign textbooks.

Since there are no special chronicles of the Mongol dynasty, there are at least the coins that have survived to this day. There are many coins that have survived almost from another dynasty of Muhammad. The importance of studying most of their distorted names has been repeatedly proven by historical, chronological, geographical and other relationships in general. Therefore, the historian of the Golden Horde must take into account these modern witnesses and not forget about their small number that are available only in Russian translations of the khan's letters. Notably, Arab historical works are important sources of medieval history of Kazakhstan and Central Asia. Such historical literature contains valuable information of a geographic, ethnic, ethnographic, economic and economic nature and provokes great academic interest for a deeper study of the past of Kazakh state. Arabic inscriptions allow for in depth studying of some aspects of the life of the medieval states that existed on the territory of Kazakhstan. Thus, the importance of Arab sources for the study of sources is one of the important elements of writing a more holistic and objective history of Kazakhstan.

Prose pieces in the Persian (Persian) language of different genres such as historical, memoir, geographical, etc. provide valuable information. Data about the history of Kazakhstan in the works of Persian authors is presented fragmentarily and is mainly related to political history, relations between a person and a ruler, studies of various khan dynasties. There is specific information on ethnic composition, economy, material and spiritual culture. The most famous Persian author is Ala ad-din Ata-Malik Juwayni (Ala Ad-Din Ata-Melik Juveini, 2021), who lived in the 13th century. The Persian historian completed "History of the Conqueror of the World" (Tarikhi Jahangush) in 1260. The author based his work on a personal trip to the Mongol-conquered regions of Turkestan, Uganda and Mongolia. His work contains important information about the 
events of the 13th century such as the siege of Otrar, the defeat of the cities of the Syr Darya, the geographical position of the Mongol ulus on the territory of Kazakhstan and the internal unrest in the Chagataid uluses.

Another valuable source is Fazlallah Rashid's "Chronicles" (Jami at-normalih), created around 1310-1311. This work is interesting for the study of the history of medieval Kazakhstan. This book contains valuable information about the peoples of Mongolia and Turkey. Rashid alDin's work was based on the official Mongolian chronicles, various historical works of the countries conquered by the Mongols, as well as information received from survivors after the described events. It contains information on the ethnic composition of the population, geographical names, the political history of states on the territory of Kazakhstan, as well as the genealogy of the Ioids. The work of this Persian author contains valuable information about customs, religion, geographic location of Turkish tribes, etc.

The historical closeness of the peoples of Central Asia and Kazakhstan is presented not only by the commonality of their history, culture, language, but also by the common spiritual and written heritage left by common ancestors. A special place in the revival of the common spiritual heritage belongs to the joint cooperation of scholars from different regions of Central Asia. The informational and communicative role of science in relations between the peoples of the region in the 21st century should increase even more, especially considering the urgent need for the historical, economic and political integration of all the peoples of Central Asia. The legitimisation of power by the Descent from Genghis Khan for many centuries determined the principles of the development of state power throughout Central Asia, Mongolia and China, in the states of the Chagataids, the Golden Horde, the Blue Horde, in the Crimea, in the Siberian khanates, in the Volga region the rulers showed their connection with the line of Genghis Khan. Thus, the Kazakh khans traced their origin from Jochi Khan. The materials of this source in comparison with other written sources, oral information, and documentary sources allow for reconstructing the history and genealogy of the Kazakh khans.

Thus, Persian sources were especially invested in the study of medieval Kazakhstan. This group of historical sources contains valuable historical, racial, ethnic, economic and economic resources of the country. Their contribution to the spread of science will expand the knowledge of the history of Kazakhstan.

\section{Conclusions}

As the review of studies reveals, most of the artifacts from archaeological sources are in the archive, and the authors often do not indicate their sources of information. As a result, the collection creates certain problems for source study and analysis of literature. At the same time, the collection helps to identify literary references, to establish the sequence of information in the main text. There is another type of collection such borrowing from others, complete and incomplete ones. However, the most common collection method is partial borrowing. Still, there is a debt shortened by authors by including or editing the author until it is corrected. The latter is less common. Advanced source study allows for mastering new tools, as well as learning the relationship between every work (text) and the source corporation (writing system) to identify the 
most instructive activities and clarify methods of collecting information from historical monuments in Kazakhstan.

As the result, it can be assumed that the Muslim Arabic written monuments between the 9th-14th centuries has survived. Kazakhstan and Central Asia are the most informed in the development of history, historical geography and culture of the peoples and tribes among the adjacent lands of Asia. Notably, research in this area requires additional efforts on the part of written sources in the Muslim community to identify and introduce new materials, as well as for a comparative study of more complete and upcoming manuscripts, the most important and valuable manuscripts of Turkey (Istanbul) and Egypt (Cairo), for a detailed and in-depth study of narrative monuments.

\section{References}

Ala Ad-Din Ata-Melik Juveini. The story of the conqueror of the world. (2021). Retrieved from http://www.vostlit.info/Texts/rus3/Juweini/text.phtml?id=10762

Archive of textbooks on history. 2021. Retrieved from http://www.padaread.com/?cat=12

Artamonov, M. (2005). History of the Arabs. St. Petersburg: Nauka.

Auanasova, A., Ayagan, B. \& Nurpeisov, E. (2019). Bases and legal status of state symbols of Kazakhstan: Histocal and legal discourse. Istoriya, 10(1). Retrieved from http://doi.org/ 10.18254/s0002558-2-1

Auanasova, A., Nurpeisov, E., Auanassova, K., Kushenova. \& G., Mukhlissov, N. (2021). The History of the Alash Party in the Context of the Impact on the Processes of Constitutional Acts. Ancient Asia, 12, $1-8$.

Barak, O. (2019). Archives and/as battlefields: Political aspects of historiographic revision. Memory Studies, 12(3), 266-278.

Begalinova, K., Ashilova, M. \& Begalinov, A. (2020). Religious extremism in Kazakhstan: Threats of spreading and means of opposition. Central Asia and the Caucasus, 21(4), 124-131.

Bernshtam, A. (2008). On the question of the emergence of classes and the state among the Turks. In: Collection of articles dedicated to the 50th anniversary of Engels' book "The Origin of the Family, Private Property and the State" (pp. 15-19). Moscow: Nauka.

Bichurin, N. (2008). Collection of information on the historical geography of Central and East Asia. Almaty: Nauka.

Bichurin, N. (2013). Collection of information about the peoples who lived in Central Asia in ancient times. Moscow: AST.

Dalelbekkyzy, A., Bisengali, Z.-G., Toleubayeva, A., Zhanat, A. \& Baitanasova, K.M. (2019). National code: Metaphysics and unity of historical consciousness. Analele Universitatii din Craiova - Seria Istorie, 35(1), 105-118.

Dautova, G., Azibayeva, B., Aimukhambet, Z., Sarekenova, K. \& Abilkhamitkyzy, R. (2017). The image of defender-hero in historical eposes. (On the materials of the Kazakh epics). Ponte, 73(10), 215-223.

Ermachkov, I.A., Koroleva, L.A., Mineeva, E.K. \& Balanyuk, L.L. (2020). Slave trade in Circassia (first half of the XIX century): Some characteristic features. Bylye Gody, 58(4), 2464-2470. 
Ermachkov, I.A., Vidishcheva, E.V., Mineeva, E.K. \& Balanyuk, L.L. (2021). The "Temporary regulation on military censorship" as a historical source. Bylye Gody, 16(2), 1008-1015.

Gumilev, L. (2003a). Ancient Russia and the Great Steppe. Moscow: AST.

Gumilev, L. (2003b). Ancient Turks. Moscow: Priroda.

Hautala, R. (2019). Comparing eastern and missionary sources on the golden Horde's history. Zolotoordynskoe Obozrenie, 7(2), 208-224.

He, N. (2019). Historical Development and Literary Representation: A Review of Post-WWII World History and the Development of Foreign Literature. Foreign Literature Studies, 41(3), 165-168.

History of Kazakhstan in Arabic sources. (2017). Retrieved from https://flibusta.site/b/590504.

Magsumov, T.A., Nizamova, M.S., Artemova, S.F. \& Allalyev, R.M. (2019a). The Akhal-Teke expeditions of 1879-1881 years: Historical and statistical study. Part 1. Bylye Gody, 53(3), 1256-1262.

Magsumov, T.A., Nizamova, M.S., Ponomareva, M.A. \& Allalyev, R.M. (2019b). The Akhal-teke expeditions of 1879-1881 years: Historical and statistical study. Part 2. Bylye Gody, 54(4), 1754-1760.

Motavalian Naeini, R. \& Dehkhodaei, Z. (2018). Spelling error analysis of Arab learners of Persian language. Language Related Research, 8(7), 233-264.

Nazzal, Y., Barbulescu, A., Howari, F., Yousef, A., Al-Taani, A.A., Al Aydaroos, F. \& Naseem, M. (2019). New insights on sand dust storm from historical records, UAE. Arabian Journal of Geosciences, 12(13), 396.

Peacock, A.C.S. (2018). Islamisation in the Golden Horde and Anatolia: Some remarks on travelling scholars and texts. Revue des Mondes Musulmans et de la Mediterranee, 143, 151-164.

Shingiray, I. (2018). An islamicate body a case study of a nomadic burial from the core territory of the Golden Horde. Revue des Mondes Musulmans et de la Mediterranee, 143, 83-106.

Stănică, A.-D. (2018). Presence of the Golden Horde at the mouth of the Danube (13th-14th centuries). The Archaeological Argument, 14(2), 51-65.

Stein, M. (2018). The history of central Asian peacekeepers: The development of Kazakhstan, Kyrgyzstan, and Tajikistan's peacekeeping units by fits and starts. Journal of Slavic Military Studies, 31(2), 257271.

Tizengauzen, V.G. (1941). Collection of materials related to the history of the Golden Horde. Moscow: USSR Academy of Sciences Publishing House.

Toonen, W.H.J., Macklin, M.G., Dawkes, G., Durcan, J.A., Leman, M., Nikolayev, Y. \& Yegorov, A. (2020). A hydromorphic reevaluation of the forgotten river civilisations of Central Asia. Proceedings of the National Academy of Sciences of the United States of America, 117(52), 32982-32988.

Turysbek, R.S., Sarekenova, K.K., Baitanasova, K.M., Myrzakhmetov, A.A. \& Aimukhambet, Z.A. (2021). The role of historical figures and legend motifs in the modern prose structure in expressing the idea of statehood. Astra Salvensis, 2021, 383-393.

Volin, S.L., Romaskevich, A.A. \& Yakubovskiy, A.Yu. (1939). Materials on the history of the Turkmen and Turkmenia. Leningrad: Publishing house of the USSR Academy of Sciences. 